\title{
New $\beta$-Caryophyllene-Derived Terpenoids from the Formosan Soft Coral Sinularia gibberosa
}

\author{
Shin-Pin Chen, ${ }^{1}$ Chih-Hua Chao, ${ }^{1}$ Ho-Cheng Huang, ${ }^{2}$ Yang-Chang Wu, ${ }^{3}$ \\ Chung-Kuang Lu, ${ }^{4,5}$ Chang-Feng Dai, ${ }^{6}$ and Jyh-Horng Sheu*1 \\ ${ }^{1}$ Department of Marine Biotechnology and Resources, National Sun Yat-sen University, Kaohsiung 804, Taiwan \\ ${ }^{2}$ Department of Chemical and Materials Engineering, Cheng Shiu University, Kaohsiung 833, Taiwan \\ ${ }^{3}$ Graduate Institute of Natural Products, Kaohsiung Medical University, Kaohsiung 807, Taiwan \\ ${ }^{4}$ National Museum of Marine Biology and Aquarium, Checheng, Pingtung 944, Taiwan \\ ${ }^{5}$ Institute of Marine Biotechnology, National Dong Hwa University, Checheng, Pingtung 944, Taiwan \\ ${ }^{6}$ Institute of Oceanography, National Taiwan University, Taipei 106, Taiwan
}

Received February 24, 2006; E-mail: sheu@mail.nsysu.edu.tw

Seven new $\beta$-caryophyllene-derived terpenoids (1-7) were isolated from EtOAc extracts of the Formosan soft coral Sinularia gibberosa. The structures of compounds 1-7 were elucidated on the basis of extensive spectroscopic analyses and by comparison with the spectral data of related metabolites. Cytotoxicity evaluation of the above metabolites towards a limited panel of cancer cell lines also will be described.

Soft corals belonging to the genus Sinularia (Alcyoniidae) have been found to be a rich source of structurally unique and biologically active diterpenoids and norditerpenoids. ${ }^{1}$ During the course of our investigation on bioactive natural products from marine invertebrates, a series of metabolites including steroids, sesquiterpenoids, diterpenoids, and norditerpenoids have been discovered. ${ }^{2-11}$ Our present study on the chemical constituents of a soft coral Sinularia gibberosa, which was collected off the coast of northeastern Taiwan, has led to the isolation of seven new $\beta$-caryophyllene-derived terpenoids (1-7) (Chart 1). We describe herein the isolation, structure elucidation, and biological activity of these compounds.

Compound 1 was isolated as a colorless oil, $[\alpha]_{\mathrm{D}}^{25}+42.8$ (c $0.16, \mathrm{CHCl}_{3}$ ). Its HR-ESI-MS had a pseudomolecular ion peak at $m / z$ 287.1622 $[\mathrm{M}+\mathrm{Na}]^{+}$(calcd for $\mathrm{C}_{16} \mathrm{H}_{24} \mathrm{O}_{3} \mathrm{Na}$, 287.1623), corresponding to the molecular formula of $\mathrm{C}_{16} \mathrm{H}_{24} \mathrm{O}_{3}$. Thus, the compound was determined to have five degrees of unsaturation. The characteristic NMR signals $\left[\delta_{\mathrm{H}}\right.$ $\left.3.69(3 \mathrm{H}, \mathrm{s}, \mathrm{OMe}) ; \delta_{\mathrm{C}} 178.3(\mathrm{C}-13), 51.9(\mathrm{OMe})\right]$ and an IR absorption at $1728 \mathrm{~cm}^{-1}$ indicated the presence of a methyl ester functional group. Furthermore, two methyls $\left(\delta_{\mathrm{C}} 16.8, \mathrm{CH}_{3}\right.$ and 17.0, $\left.\mathrm{CH}_{3}\right)$, one trisubstituted epoxide $\left(\delta_{\mathrm{C}} 59.4, \mathrm{C}\right.$ and 63.4, $\mathrm{CH})$, and one exocyclic double bond $\left(\delta_{\mathrm{C}} 114.0, \mathrm{CH}_{2}\right.$ and 150.6, C) were assigned from the ${ }^{13} \mathrm{CNMR}$ and DEPT spectra of compound $\mathbf{1}$. The above functionalities revealed that compound $\mathbf{1}$ is a tricyclic compound, including the presence of an epoxide. Using 2D NMR spectroscopic analysis (COSY, HMQC, and HMBC), the caryophyllene-based skeleton of compound 1 was elucidated (Fig. 1).

The relative stereochemistry of compound $\mathbf{1}$ (Fig. 2) was established from NOE correlations observed in a NOESY experiment. In the NOESY spectrum of compound 1, H-1 interacted

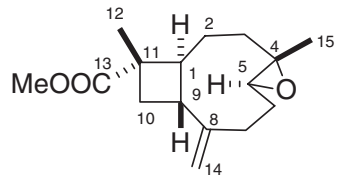

1

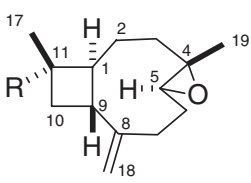

2: $\mathrm{R}=$<smiles>CC(=O)CCC(C)=O</smiles><smiles>CC(=O)CCC(C)OC(C)=O</smiles><smiles>C=C1CCC2O[C@]2(C)CC[C@H]2C[C@](C)(C(=O)/C=C/C(C)(C)OO)[C@H]12</smiles>

4<smiles>C=C1CC2O[C@]2(C)CC[C@H]1C(=O)O</smiles>

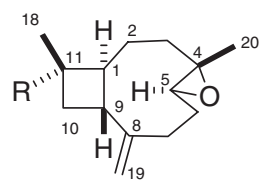

3: $R=$<smiles>CC(=O)/C=C/C(C)(O)F</smiles>

5: $R=$<smiles>CC(=O)CCC(C)(C)OC(C)=O</smiles>

6: $R=$<smiles>CCC(C)=CCC(C)=O</smiles>

9: $\mathrm{R}=\mathrm{OH}$

11: $R=$<smiles>CC(=O)C=CC(C)(C)O</smiles>

Chart 1. 

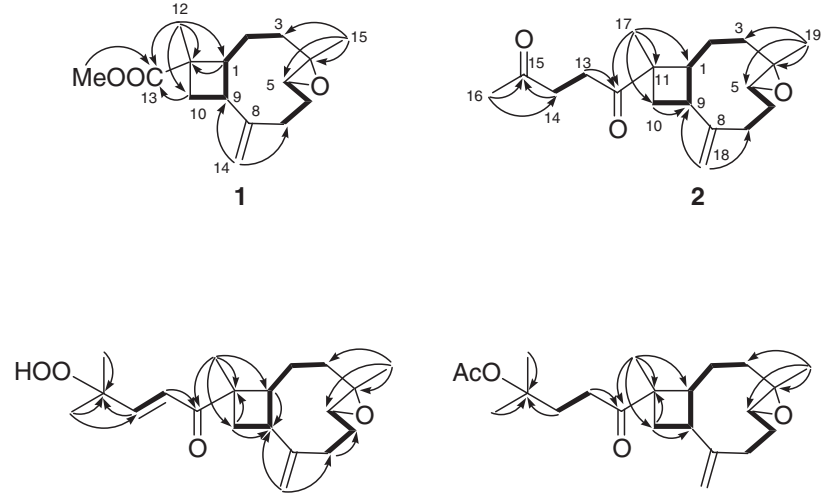

3 and 4

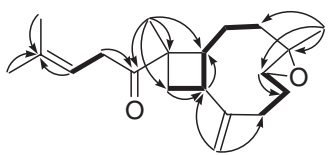

6

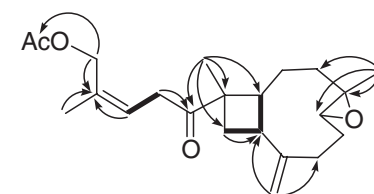

Fig. 1. Selective ${ }^{1} \mathrm{H}-{ }^{1} \mathrm{H}$ COSY and HMBC correlations of compounds 1-7.

with $\mathrm{H}-5$ but not with $\mathrm{H}-9, \mathrm{H}_{3}-12$, and $\mathrm{H}_{3}-15$, suggesting that $\mathrm{H}-1$ is situated on the opposite face of the compound from $\mathrm{H}-9, \mathrm{H}_{3}-12$, and $\mathrm{H}_{3}-15$. It was found that the relative stereochemistry of compound $\mathbf{1}$ is the same as that of a known metabolite 8. ${ }^{12,13}$ Also, we have previously isolated a related norcaryophyllene, compound $\mathbf{9}$, from a soft coral of the same genus Sinularia. ${ }^{6}$ Thus, a $\left(1 S^{*}, 4 S^{*}, 5 S^{*}, 9 R^{*}, 11 S^{*}\right)$-configuration for compound $\mathbf{1}$ was suggested.

Gibberosin A (2) was obtained as a colorless oil, $[\alpha]_{\mathrm{D}}^{25}$ +43.2 ( $c$ 1.04, $\mathrm{CHCl}_{3}$ ). The molecular formula of compound 2, $\mathrm{C}_{19} \mathrm{H}_{28} \mathrm{O}_{3}$, was established by HR-ESI-MS, and it was determined to have six degrees of unsaturation. The ${ }^{13} \mathrm{C}$ NMR spectrum of compound $\mathbf{2}$ had signals for 19 carbons (Table 1), including those of two ketones $\left(\delta_{\mathrm{C}} 213.4\right.$ and 207.6), one trisubstituted epoxide $\left(\delta_{\mathrm{C}} 59.5, \mathrm{C}\right.$ and $\left.63.7, \mathrm{CH}\right)$, and one exocyclic double bond $\left(\delta_{\mathrm{C}} 114.2, \mathrm{CH}_{2}\right.$ and $\left.150.8, \mathrm{C}\right)$. From a comparison of ${ }^{1} \mathrm{H}$ and ${ }^{13} \mathrm{C}$ NMR spectral data of compound 2 (Tables 1 and 2) with those of compound $\mathbf{1}$ and nanolobatin $\mathrm{C}(\mathbf{1 0}),{ }^{6}$ it was found that compound $\mathbf{2}$ contains the same ring structure as that of compounds $\mathbf{1}$ and $\mathbf{1 0}$, and the acetoxy-bearing methine at $\mathrm{C}-15$ in compound $\mathbf{1 0}$ was replaced by a ketone in compound 2, which was also confirmed by the HMBC and COSY correlations as shown in Fig. 1. Thus, the planar structure of compound 2 was fully established. From the NOE correlations observed in the NOESY spectrum of 2 (Fig. 2), H-1 interacted with $\mathrm{H}-5$, but not with $\mathrm{H}-9, \mathrm{H}_{3}-17$, and $\mathrm{H}_{3}-19$. Also, $\mathrm{H}-5$ did not interact with $\mathrm{H}_{3}-19$. This suggests that $\mathrm{H}-5$ has an $\alpha$-orientation and $\mathrm{H}-9, \mathrm{H}_{3}-17$, and $\mathrm{H}_{3}-19$ have $\beta$-orientation. Therefore, the relative configurations on C-1, C-4, C-5, C-9, and $\mathrm{C}-11$ in compound 2 were found to be the same as those of compound $\mathbf{1}$.

Gibberosin B (3) was obtained as a colorless oil, $[\alpha]_{\mathrm{D}}^{25}$ +32.1 ( $c$ 0.28, $\left.\mathrm{CHCl}_{3}\right)$. According to the HR-ESI-MS $(\mathrm{m} / \mathrm{z}$ 357.2041, $\left.[\mathrm{M}+\mathrm{Na}]^{+}\right)$and ${ }^{13} \mathrm{CNMR}$ data, its molecular for-

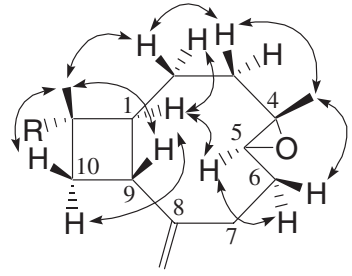

1: $\mathrm{R}=\mathrm{COOMe}$

2: $\mathrm{R}=$<smiles>CC(=O)CCC(C)=O</smiles>

3: $\mathrm{R}=$<smiles>CC(=O)C=CC(C)(C)O</smiles>

5: $\mathrm{R}=$<smiles>CC(=O)CCC(C)(C)OC(C)=O</smiles>

6: $R=$<smiles>CC(=O)CC=C(C)C</smiles>

7: $\mathrm{R}=$<smiles>CC(=O)CC=CCCCCCOC(C)=O</smiles>

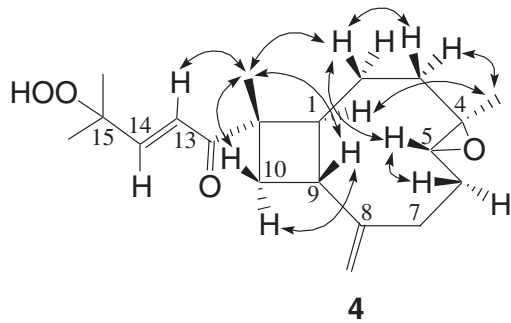

Fig. 2. Key NOESY correlations of compounds 1-7.

mula is $\mathrm{C}_{20} \mathrm{H}_{30} \mathrm{O}_{4} \mathrm{Na}$. Therefore, compound $\mathbf{3}$ was determined to have six degrees of unsaturation. The ${ }^{1} \mathrm{H}$ and ${ }^{13} \mathrm{CNMR}$ spectral data were very similar to those of a known compound $11^{6}$ (Tables 1 and 2) except that a carbon signal at $\delta 71.2$ (C-15) in compound $\mathbf{1 1}$ was shifted to $\delta 82.2$ in compound 3. Furthermore, the ${ }^{1} \mathrm{H}$ NMR spectrum of compound $\mathbf{3}$ showed an additional signal at $\delta 7.51$ (br s) which was considered to be a hydroperoxy proton. ${ }^{14}$ In other words, the hydroxy group in compound $\mathbf{1 1}$ was replaced by a hydroperoxy group in compound 3. The double bond between $\mathrm{C}-13$ and $\mathrm{C}-14$ was determined to have a trans geometry based on the coupling constant $(J=15.9 \mathrm{~Hz})$ between $\mathrm{H}-13(\delta 6.34, \mathrm{~d})$ and $\mathrm{H}-14(\delta 6.92, \mathrm{~d})$. The relative configurations on C-1, C-4, C-5, C-9, and C-11 in compound $\mathbf{3}$ were found to be the same as those of compounds 2 and 11, on the basis of the NOE correlations observed in a NOESY experiment as shown in Fig. 2.

Gibberosin C (4) was isolated as a colorless oil, $[\alpha]_{\mathrm{D}}^{25}+13.3$ (c $0.32, \mathrm{CHCl}_{3}$ ). Its HR-ESI-MS established the same molecular formula, $\mathrm{C}_{20} \mathrm{H}_{30} \mathrm{O}_{4}$, as that of compound 3. The ${ }^{1} \mathrm{H}$ and ${ }^{13} \mathrm{CNMR}$ data of compound 4 (Tables 1 and 2, respectively) are very similar to those of compound $\mathbf{3}$. Careful inspection 
Table $1 .{ }^{13}$ C NMR Spectral Data of Compounds 1-7

\begin{tabular}{|c|c|c|c|c|c|c|c|}
\hline C\# & $\mathbf{1}^{\mathrm{a})}$ & $2^{\mathrm{a})}$ & $3^{\text {a) }}$ & $4^{b)}$ & $5^{\mathrm{c})}$ & $6^{\mathrm{a})}$ & $7^{\mathrm{b})}$ \\
\hline 1 & $47.2(\mathrm{CH})^{\mathrm{d})}$ & $45.4(\mathrm{CH})$ & $45.1(\mathrm{CH})$ & $48.3(\mathrm{CH})$ & $45.5(\mathrm{CH})$ & $45.3(\mathrm{CH})$ & $45.5(\mathrm{CH})$ \\
\hline 2 & $27.6\left(\mathrm{CH}_{2}\right)$ & $28.1\left(\mathrm{CH}_{2}\right)$ & $28.1\left(\mathrm{CH}_{2}\right)$ & $28.6\left(\mathrm{CH}_{2}\right)$ & $28.1\left(\mathrm{CH}_{2}\right)$ & $28.0\left(\mathrm{CH}_{2}\right)$ & $28.2\left(\mathrm{CH}_{2}\right)$ \\
\hline 3 & $38.6\left(\mathrm{CH}_{2}\right)$ & $38.5\left(\mathrm{CH}_{2}\right)$ & $38.5\left(\mathrm{CH}_{2}\right)$ & $35.8\left(\mathrm{CH}_{2}\right)$ & $38.6\left(\mathrm{CH}_{2}\right)$ & $38.5\left(\mathrm{CH}_{2}\right)$ & $38.7\left(\mathrm{CH}_{2}\right)$ \\
\hline 4 & $59.4(\mathrm{C})$ & $59.5(\mathrm{C})$ & $59.6(\mathrm{C})$ & $60.7(\mathrm{C})$ & $59.1(\mathrm{C})$ & $59.5(\mathrm{C})$ & $59.7(\mathrm{C})$ \\
\hline 5 & $63.4(\mathrm{CH})$ & $63.7(\mathrm{CH})$ & $63.6(\mathrm{CH})$ & $61.0(\mathrm{CH})$ & $63.7(\mathrm{CH})$ & $63.6(\mathrm{CH})$ & $63.8(\mathrm{CH})$ \\
\hline 6 & $30.0\left(\mathrm{CH}_{2}\right)$ & $30.2\left(\mathrm{CH}_{2}\right)$ & $30.1\left(\mathrm{CH}_{2}\right)$ & $36.3\left(\mathrm{CH}_{2}\right)$ & $30.1\left(\mathrm{CH}_{2}\right)$ & $30.1\left(\mathrm{CH}_{2}\right)$ & $30.3\left(\mathrm{CH}_{2}\right)$ \\
\hline 7 & $29.7\left(\mathrm{CH}_{2}\right)$ & $29.4\left(\mathrm{CH}_{2}\right)$ & $29.5\left(\mathrm{CH}_{2}\right)$ & $29.5\left(\mathrm{CH}_{2}\right)$ & $29.6\left(\mathrm{CH}_{2}\right)$ & $\left.29.4 \mathrm{CH}_{2}\right)$ & $29.7\left(\mathrm{CH}_{2}\right)$ \\
\hline 8 & $150.6(\mathrm{C})$ & $150.8(\mathrm{C})$ & $150.6(\mathrm{C})$ & $151.6(\mathrm{C})$ & $151.6(\mathrm{C})$ & $150.1(\mathrm{C})$ & $150.8(\mathrm{C})$ \\
\hline 9 & $47.8(\mathrm{CH})$ & $47.4(\mathrm{CH})$ & $47.3(\mathrm{CH})$ & $45.6(\mathrm{CH})$ & $48.5(\mathrm{CH})$ & $47.2(\mathrm{CH})$ & $47.4(\mathrm{CH})$ \\
\hline 10 & $35.4\left(\mathrm{CH}_{2}\right)$ & $35.0\left(\mathrm{CH}_{2}\right)$ & $35.1\left(\mathrm{CH}_{2}\right)$ & $37.6\left(\mathrm{CH}_{2}\right)$ & $35.2\left(\mathrm{CH}_{2}\right)$ & $35.2\left(\mathrm{CH}_{2}\right)$ & $35.3\left(\mathrm{CH}_{2}\right)$ \\
\hline 11 & $42.0(\mathrm{C})$ & $48.2(\mathrm{C})$ & $47.7(\mathrm{C})$ & $46.8(\mathrm{C})$ & $47.3(\mathrm{C})$ & $48.4(\mathrm{C})$ & 48.7 (C) \\
\hline 12 & $16.8\left(\mathrm{CH}_{3}\right)$ & $213.4(\mathrm{C})$ & $203.3(\mathrm{C})$ & $203.3(\mathrm{C})$ & $213.4(\mathrm{C})$ & $212.6(\mathrm{C})$ & $211.8(\mathrm{C})$ \\
\hline 13 & $178.3(\mathrm{C})$ & $30.6\left(\mathrm{CH}_{2}\right)$ & $123.0(\mathrm{CH})$ & $123.0(\mathrm{CH})$ & $31.3\left(\mathrm{CH}_{2}\right)$ & $36.5\left(\mathrm{CH}_{2}\right)$ & $35.8\left(\mathrm{CH}_{2}\right)$ \\
\hline 14 & $114.0\left(\mathrm{CH}_{2}\right)$ & $36.8\left(\mathrm{CH}_{2}\right)$ & $149.3(\mathrm{CH})$ & $149.1(\mathrm{CH})$ & $34.9\left(\mathrm{CH}_{2}\right)$ & $116.1(\mathrm{CH})$ & $122.2(\mathrm{CH})$ \\
\hline 15 & $17.0\left(\mathrm{CH}_{3}\right)$ & $207.6(\mathrm{C})$ & $82.2(\mathrm{C})$ & $82.2(\mathrm{C})$ & $81.5(\mathrm{C})$ & $134.5(\mathrm{C})$ & $133.6(\mathrm{C})$ \\
\hline 16 & & $30.1\left(\mathrm{CH}_{3}\right)$ & $24.2\left(\mathrm{CH}_{3}\right)$ & $24.2\left(\mathrm{CH}_{3}\right)$ & $25.9\left(\mathrm{CH}_{3}\right)$ & $18.1\left(\mathrm{CH}_{3}\right)$ & $63.3\left(\mathrm{CH}_{2}\right)$ \\
\hline 17 & & $16.9\left(\mathrm{CH}_{3}\right)$ & $24.2\left(\mathrm{CH}_{3}\right)$ & $24.2\left(\mathrm{CH}_{3}\right)$ & $25.9\left(\mathrm{CH}_{3}\right)$ & $25.7\left(\mathrm{CH}_{3}\right)$ & $21.8\left(\mathrm{CH}_{3}\right)$ \\
\hline 18 & & $114.2\left(\mathrm{CH}_{2}\right)$ & $16.9\left(\mathrm{CH}_{3}\right)$ & $16.8\left(\mathrm{CH}_{3}\right)$ & $17.1\left(\mathrm{CH}_{3}\right)$ & $17.0\left(\mathrm{CH}_{3}\right)$ & $17.0\left(\mathrm{CH}_{3}\right)$ \\
\hline 19 & & $17.2\left(\mathrm{CH}_{3}\right)$ & $114.1\left(\mathrm{CH}_{2}\right)$ & $113.3\left(\mathrm{CH}_{2}\right)$ & $114.2\left(\mathrm{CH}_{2}\right)$ & $114.0\left(\mathrm{CH}_{2}\right)$ & $114.4\left(\mathrm{CH}_{2}\right)$ \\
\hline 20 & & & $17.1\left(\mathrm{CH}_{3}\right)$ & $22.4\left(\mathrm{CH}_{3}\right)$ & $16.9\left(\mathrm{CH}_{3}\right)$ & $16.8\left(\mathrm{CH}_{3}\right)$ & $17.3\left(\mathrm{CH}_{3}\right)$ \\
\hline \multirow[t]{2}{*}{ OAc } & & & & & $170.7(\mathrm{C})$ & & $171.2(\mathrm{C})$ \\
\hline & & & & & $22.3\left(\mathrm{CH}_{3}\right)$ & & $21.1\left(\mathrm{CH}_{3}\right)$ \\
\hline $\mathrm{OMe}$ & $51.9\left(\mathrm{CH}_{3}\right)$ & & & & & & \\
\hline
\end{tabular}

a) Spectra recorded at $100 \mathrm{MHz}$ in $\mathrm{CDCl}_{3}$ at $25^{\circ} \mathrm{C}$. b) Spectra recorded at $125 \mathrm{MHz}$ in $\mathrm{CDCl}_{3}$ at $25^{\circ} \mathrm{C}$. c) Spectra recorded at $75 \mathrm{MHz}$ in $\mathrm{CDCl}_{3}$ at $25^{\circ} \mathrm{C}$. d) Attached protons were deduced by DEPT spectra. The values are in ppm downfield from TMS.

of the ${ }^{1} \mathrm{H}-{ }^{1} \mathrm{H}$ COSY and HMBC spectral data of compound 4 showed that compound $\mathbf{4}$ had a planar structure similar to that of compound 3 (Fig. 1). The relative stereochemistry of compound 4 was elucidated by analysis of the vicinal ${ }^{1} \mathrm{H}-{ }^{1} \mathrm{H}$ coupling constants and NOE correlations observed in a NOESY experiment. The double bond between $\mathrm{C}-13$ and $\mathrm{C}-14$ was also determined to have a trans geometry based on the coupling constant $(J=15.5 \mathrm{~Hz})$ between $\mathrm{H}-13(\delta 6.35$, d) and $\mathrm{H}-14$ $(\delta 6.94, \mathrm{~d})$. In the NOESY spectrum of compound 4 , H-1 interacted with $\mathrm{H}_{3}-20$ but not with $\mathrm{H}-5, \mathrm{H}-9$, and $\mathrm{H}_{3}-18$, suggesting that $\mathrm{H}-1$ and $\mathrm{H}_{3}-20$ have an $\alpha$-orientation and $\mathrm{H}-5, \mathrm{H}-9$, and $\mathrm{H}_{3}-18$ have a $\beta$-orientation. Therefore, compound 4 was determined to be a C-4, C-5 diastereomer of compound 3 .

Gibberosin D (5) has the molecular formula $\mathrm{C}_{22} \mathrm{H}_{34} \mathrm{O}_{4}$ based on its HR-ESI-MS and NMR spectral data (Tables 1 and 2, respectively). Comparison of the ${ }^{13} \mathrm{C}$ NMR spectral data of compound $\mathbf{5}$ with those of compound $\mathbf{3}$ (Table 1) suggested that compound $\mathbf{5}$ is another caryophyllene-derived diterpeneoid. From careful inspection on the ${ }^{1} \mathrm{H}$ and ${ }^{13} \mathrm{C}$ NMR spectral data of compound 5, C-12 was assigned to have a saturated prenyl substituent. Also, two methyl groups $\left(\delta_{\mathrm{H}} 1.44(6 \mathrm{H}, \mathrm{s})\right.$ and $\left.\delta_{\mathrm{C}} 25.9\right)$ were attached to $\mathrm{C}-15$, and an acetoxy group $\left(\delta_{\mathrm{C}} 22.3\right.$ and 170.7; IR absorption at $1734 \mathrm{~cm}^{-1}$ ) was found to be attached to $\mathrm{C}-15\left(\delta_{\mathrm{C}} 81.5 ; \delta_{\mathrm{H}}\left(\mathrm{H}_{3}-16\right.\right.$ and $\left.\mathrm{H}_{3}-17\right) 1.44$, $6 \mathrm{H}, \mathrm{s})$. Based on the data, the molecular framework of compound $\mathbf{5}$ was determined. In addition, the stereochemistry of compound $\mathbf{5}$ was established based on key NOE correlations (Fig. 2).

Gibberosin E (6) was isolated as a colorless oil, $[\alpha]_{\mathrm{D}}^{25}+25.0$ (c $0.44, \mathrm{CHCl}_{3}$ ). The molecular formula of compound 6 was determined to be $\mathrm{C}_{20} \mathrm{H}_{30} \mathrm{O}_{2}$ based on HR-ESI-MS, and it has six degrees of unsaturation. The ${ }^{1} \mathrm{H}$ and ${ }^{13} \mathrm{C}$ NMR data of compound 6 revealed that this compound has the same ring skeleton as those of compounds $\mathbf{1 - 5}$. An IR absorption at 1670 $\mathrm{cm}^{-1}$ corresponded to a trisubsituted double bond. In the ${ }^{1}$ HNMR spectrum, no signal was observed for an acetoxy group; however, an additional olefinic proton $(\delta 5.28, J=7.8$, $7.8,1.2 \mathrm{~Hz}$ ), as compared to that of compound $\mathbf{5}$ was observed. Based on these findings, together with the correlations observed in the ${ }^{1} \mathrm{H}-{ }^{1} \mathrm{H}$ COSY and HMBC spectra (Fig. 1), compound 6 was determined to have a planar structure. The relative stereochemistry of caryophyllene-based moiety for compound $\mathbf{6}$ was found to be the same as that of compound $\mathbf{5}$, determined from the NOE correlations observed in a NOESY spectrum (Fig. 2).

Gibberosin F (7) was obtained as a colorless oil, $[\alpha]_{\mathrm{D}}^{25}$ +68.7 ( $c 0.16, \mathrm{CHCl}_{3}$ ). The molecular formula of compound 7 was determined to be $\mathrm{C}_{22} \mathrm{H}_{32} \mathrm{O}_{4}$ based on HR-ESI-MS. The ${ }^{1} \mathrm{H}$ and ${ }^{13} \mathrm{C}$ NMR data are very similar to those of compound 6 . By comparison of the NMR spectral data of compound $\mathbf{6}$ with those of compound 7, it was found that a vinyl methyl attached to $\mathrm{C}-15$ in compound 6 was replaced by an acetoxy-bearing methylene in compound 7. The HMBC cross peaks from $\mathrm{H}_{3}-17$ to $\mathrm{C}-15$, and $\mathrm{H}_{2}-16$ to $\mathrm{C}-15$ and the acetoxy carbonyl carbon confirmed the above observation. The double bound between $\mathrm{C}-14$ and $\mathrm{C}-15$ was determined to have a cis geometry based on the NOE interaction between $\mathrm{H}-14$ and $\mathrm{H}_{3}-17$.

The caryophyllene moiety in compounds 2, 3, and 5-7 now are known to have the same relative stereochemistry at the asymmetric carbons, C-1, C-4, C-5, C-9, and C-11 as that in compound 1. Thus, the relative configurations of these five compounds were assigned to be $1 S^{*}, 4 S^{*}, 5 S^{*}, 9 R^{*}, 11 S^{*}$. How- 
Table 2. ${ }^{1} \mathrm{H}$ NMR Spectral Data of Compounds 1-7

\begin{tabular}{|c|c|c|c|c|c|c|c|}
\hline $\mathrm{H \#}$ & $1^{\text {a) }}$ & $2^{\text {a) }}$ & $3^{\text {a) }}$ & $4^{\mathrm{b})}$ & $5^{\mathrm{c})}$ & $6^{\mathrm{a})}$ & $7^{\mathrm{b})}$ \\
\hline 1 & $\begin{array}{l}2.46 \mathrm{dd} \\
(9.6,9.6)^{\mathrm{d})}\end{array}$ & $\begin{array}{l}2.48 \mathrm{dd} \\
(10.0,10.0)\end{array}$ & $\begin{array}{l}2.46 \mathrm{dd} \\
(10.0,10.0)\end{array}$ & $\begin{array}{l}2.43 \mathrm{dd} \\
(10.0,10.0)\end{array}$ & $2.42 \mathrm{~m}$ & $\begin{array}{l}2.43 \mathrm{dd} \\
(9.6,9.6)\end{array}$ & $2.45 \mathrm{~m}$ \\
\hline \multirow[t]{2}{*}{2} & $\alpha 1.82 \mathrm{~m}$ & $1.81 \mathrm{~m}$ & $1.83 \mathrm{~m}$ & $1.74 \mathrm{~m}$ & $1.78 \mathrm{~m}$ & $1.80 \mathrm{~m}$ & $1.85 \mathrm{~m}$ \\
\hline & $\beta 1.51 \mathrm{~m}$ & $1.54 \mathrm{~m}$ & $1.59 \mathrm{~m}$ & $1.57 \mathrm{~m}$ & $1.57 \mathrm{~m}$ & $1.53 \mathrm{~m}$ & $1.57 \mathrm{~m}$ \\
\hline \multirow[t]{2}{*}{3} & $\alpha^{1.03 \mathrm{~m}}$ & $\begin{array}{l}1.10 \mathrm{ddd} \\
(12.8,12.8,3.6)\end{array}$ & $1.09 \mathrm{~m}$ & $1.90 \mathrm{~m}$ & $1.09 \mathrm{~m}$ & $\begin{array}{l}1.07 \mathrm{ddd} \\
(12.8,12.8,4.8)\end{array}$ & $\begin{array}{l}1.07 \mathrm{ddd} \\
(13.0,13.0,5.0)\end{array}$ \\
\hline & $\beta^{2.09 \mathrm{~m}}$ & $\begin{array}{l}2.09 \mathrm{ddd} \\
(12.8,12.8,3.6)\end{array}$ & $2.14 \mathrm{~m}$ & $1.72 \mathrm{~m}$ & $2.10 \mathrm{~m}$ & $\begin{array}{l}2.09 \mathrm{ddd} \\
(12.4,12.4,3.6)\end{array}$ & $2.08 \mathrm{~m}$ \\
\hline 5 & $\begin{array}{l}2.89 \mathrm{dd} \\
(10.4,4.4)\end{array}$ & $\begin{array}{l}2.93 \mathrm{dd} \\
(10.4,3.6)\end{array}$ & $\begin{array}{l}2.89 \mathrm{dd} \\
(10.4,3.6)\end{array}$ & $\begin{array}{l}3.00 \mathrm{dd} \\
(11.5,2.5)\end{array}$ & $\begin{array}{l}2.89 \mathrm{dd} \\
(10.5,3.6)\end{array}$ & $\begin{array}{l}2.88 \mathrm{dd} \\
(10.4,4.0)\end{array}$ & $\begin{array}{l}2.89 \mathrm{dd} \\
(10.0,3.5)\end{array}$ \\
\hline \multirow[t]{2}{*}{6} & $\alpha 2.27 \mathrm{~m}$ & $2.31 \mathrm{~m}$ & $2.28 \mathrm{~m}$ & $2.57 \mathrm{~m}$ & $2.21 \mathrm{~m}$ & $2.27 \mathrm{~m}$ & $2.29 \mathrm{~m}$ \\
\hline & $\beta 1.37 \mathrm{~m}$ & $1.32 \mathrm{~m}$ & $1.30 \mathrm{~m}$ & & $1.29 \mathrm{~m}$ & $1.30 \mathrm{~m}$ & $1.29 \mathrm{~m}$ \\
\hline \multirow[t]{2}{*}{7} & $\alpha 2.38 \mathrm{~m}$ & $2.34 \mathrm{~m}$ & $2.30 \mathrm{~m}$ & $2.24 \mathrm{~m}$ & $2.20 \mathrm{~m}$ & $2.32 \mathrm{~m}$ & $2.30 \mathrm{~m}$ \\
\hline & $\beta 2.12 \mathrm{~m}$ & $2.17 \mathrm{~m}$ & $2.16 \mathrm{~m}$ & $2.14 \mathrm{~m}$ & $2.15 \mathrm{~m}$ & $2.16 \mathrm{~m}$ & $2.15 \mathrm{~m}$ \\
\hline 9 & $\begin{array}{l}2.68 \mathrm{q} \\
(10.0)\end{array}$ & $2.69 \mathrm{~m}$ & $\begin{array}{l}2.73 \mathrm{q} \\
(9.0)\end{array}$ & $\begin{array}{l}2.4 \mathrm{q} \\
(9.0)\end{array}$ & $\begin{array}{l}2.68 \mathrm{q} \\
(9.6)\end{array}$ & $\begin{array}{l}2.69 \mathrm{q} \\
(10.0)\end{array}$ & $2.70 \mathrm{~m}$ \\
\hline \multirow[t]{2}{*}{10} & $\alpha 2.31 \mathrm{~m}$ & $2.24 \mathrm{~m}$ & $2.17 \mathrm{~m}$ & $2.17 \mathrm{~m}$ & $2.17 \mathrm{~m}$ & $2.22 \mathrm{~m}$ & $2.14 \mathrm{~m}$ \\
\hline & $\begin{array}{ll}\beta 1.76 \mathrm{~m} \\
1.32 \mathrm{~s}\end{array}$ & $1.77 \mathrm{~m}$ & $1.87 \mathrm{~m}$ & $2.04 \mathrm{~m}$ & $1.77 \mathrm{~m}$ & $1.77 \mathrm{~m}$ & $1.83 \mathrm{~m}$ \\
\hline 13 & & $2.66 \mathrm{~m}$ & $\begin{array}{l}6.34 \mathrm{~d} \\
(15.9)\end{array}$ & $\begin{array}{l}6.35 \mathrm{~d} \\
(15.5)\end{array}$ & $2.45 \mathrm{~m}$ & $\begin{array}{l}3.06 \mathrm{dd} \\
(18.0,7.8) \\
3.13 \mathrm{dd} \\
(18.0,7.8)\end{array}$ & $\begin{array}{l}3.21 \mathrm{dd} \\
(18.0,6.5) \\
3.28 \mathrm{dd} \\
(18.0,6.5)\end{array}$ \\
\hline \multirow[t]{2}{*}{14} & $4.93 \mathrm{~s}$ & $2.72 \mathrm{~m}$ & $\begin{array}{l}6.92 \mathrm{~d} \\
(15.9)\end{array}$ & $\begin{array}{l}6.94 \mathrm{~d} \\
(15.5)\end{array}$ & $2.02 \mathrm{~m}$ & $\begin{array}{l}5.28 \mathrm{dd} \mathrm{m}^{\mathrm{e})} \\
(7.8,7.8,1.2)\end{array}$ & $\begin{array}{l}5.58 \mathrm{dd} \\
(6.5,6.5)\end{array}$ \\
\hline & $5.05 \mathrm{~s}$ & & & & & & \\
\hline 15 & $1.21 \mathrm{~s}$ & & & & & & \\
\hline 16 & & $2.19 \mathrm{~s}$ & $1.38 \mathrm{~s}$ & $1.39 \mathrm{~s}$ & $1.44 \mathrm{~s}$ & $1.61 \mathrm{~s}$ & $4.52 \mathrm{~s}$ \\
\hline 17 & & $1.33 \mathrm{~s}$ & $1.39 \mathrm{~s}$ & $1.40 \mathrm{~s}$ & $1.44 \mathrm{~s}$ & $1.75 \mathrm{~s}$ & $1.81 \mathrm{~s}$ \\
\hline 18 & & $\begin{array}{l}4.90 \mathrm{~s} \\
5.01 \mathrm{~s}\end{array}$ & $1.31 \mathrm{~s}$ & $1.28 \mathrm{~s}$ & $1.31 \mathrm{~s}$ & $1.32 \mathrm{~s}$ & $1.32 \mathrm{~s}$ \\
\hline 19 & & $1.20 \mathrm{~s}$ & $\begin{array}{l}4.91 \mathrm{~s} \\
5.00 \mathrm{~s}\end{array}$ & $\begin{array}{l}5.03 \mathrm{~s} \\
5.08 \mathrm{~s}\end{array}$ & $\begin{array}{l}4.91 \mathrm{~s} \\
5.00 \mathrm{~s}\end{array}$ & $\begin{array}{l}4.90 \mathrm{~s} \\
5.00 \mathrm{~s}\end{array}$ & $\begin{array}{l}4.90 \mathrm{~s} \\
5.00 \mathrm{~s}\end{array}$ \\
\hline 20 & & & $1.21 \mathrm{~s}$ & $1.25 \mathrm{~s}$ & $1.18 \mathrm{~s}$ & $1.20 \mathrm{~s}$ & $1.20 \mathrm{~s}$ \\
\hline OAc & & & & & $1.97 \mathrm{~s}$ & & $2.06 \mathrm{~s}$ \\
\hline $\mathrm{OMe}$ & $3.69 \mathrm{~s}$ & & & & & & \\
\hline $\mathrm{OOH}$ & & & $7.51 \mathrm{~s}$ & $7.51 \mathrm{~s}$ & & & \\
\hline
\end{tabular}

a) Spectra recorded at $400 \mathrm{MHz}$ in $\mathrm{CDCl}_{3}$ at $25^{\circ} \mathrm{C}$. b) Spectra recorded at $500 \mathrm{MHz}$ in $\mathrm{CDCl}_{3}$ at $25^{\circ} \mathrm{C}$. c) Spectra recorded at 300 $\mathrm{MHz}$ in $\mathrm{CDCl}_{3}$ at $25^{\circ} \mathrm{C}$. The values are in ppm downfield from TMS. d) $J$ value (in $\mathrm{Hz}$ ) in parentheses. e) $\mathrm{m}$ is equal to septet.

ever, compound 4 was assumed to possess a $\left(1 S^{*}, 4 R^{*}, 5 R^{*},-\right.$ $\left.9 R^{*}, 11 S^{*}\right)$ configuration as $\mathrm{H}-1$ and $\mathrm{H}_{3}-20$ were found to be positioned on the $\alpha$ face.

Cytotoxicity of metabolites 1-7 toward a limited panel of cancer cell lines was evaluated. Compound $\mathbf{3}$ had weak cytotoxicity towards Hep G2 (Human hepatocellular carcinoma), A549 (human lung carcinoma), and MDA-MB-231 (human breast carcinoma) cell lines with $\mathrm{IC}_{50}$ 's of $18.7,18.5$, and $15.2 \mu \mathrm{g} \mathrm{mL}^{-1}$, respectively. Also, metabolite 6 had weak cytotoxicity $\left(\mathrm{IC}_{50} 16.3 \mu \mathrm{g} \mathrm{mL}^{-1}\right.$ ) towards MDA-MB-231. The other metabolites were inactive toward the growth of the above three cancer cell lines.

\section{Experimental}

General Experimental Procedures. Optical rotations were measured on a Jasco DIP-1000 digital polarimeter. IR spectra were recorded on a Jasco FT-5300 infrared spectrophotometer.
NMR spectra were recorded on a Bruker Avance DPX300 FTNMR at $300 \mathrm{MHz}$ for ${ }^{1} \mathrm{H}$ and $75 \mathrm{MHz}$ for ${ }^{13} \mathrm{C}$ or on a Varian Unity INOVA $500 \mathrm{FT}-\mathrm{NMR}$ at $500 \mathrm{MHz}$ for ${ }^{1} \mathrm{H}$ and $125 \mathrm{MHz}$ for ${ }^{13} \mathrm{C}$, in $\mathrm{CDCl}_{3}$ using TMS as an internal standard. Low-resolution mass data and HR-MS data were recorded by ESI FT-MS on a Bruker APEX II mass spectrometer. Silica gel (Merck, 230-400 mesh) was used for column chromatography. Precoated silica gel plates (Merck, Kieselgel 60 F-254, $0.2 \mathrm{~mm}$ ) were used for analytical TLC. High-performance liquid chromatography (HPLC) was performed on a Hitachi L-7100 apparatus equipped with a Bischoff refractive index detector, or a Hitachi L-7400 UV detector and with the Merck Hibar Si-60 column $(250 \times 21 \mathrm{~mm}, 7 \mu \mathrm{m})$.

Animal Material. The soft coral Sinularia gibberosa was collected by hand using scuba equipment off the coast of northeastern Taiwan, in May, 2004, at a depth of 15-20 m, and was stored in a freezer until extraction. A voucher specimen was deposited in the Department of Marine Biotechnology and Resources, National Sun Yat-sen University (specimen No. 20040621-5). 
Extraction and Isolation. The soft coral $S$. gibberosa $(1.3 \mathrm{~kg}$ fresh wt) was collected and freeze dried. The freeze-dried material was minced and extracted exhaustively with EtOAc. The EtOAc extract $(15.4 \mathrm{~g})$ was fractionated by using open column chromatography on silica gel using hexane and hexane-EtOAc mixtures of increasing polarity to yield 32 fractions. Fraction 6 , eluted with hexane/EtOAc (8:1), was subjected to Sephadex LH-20 column $(2 \times 90 \mathrm{~cm})$ using Acetone, which was followed by normal phase HPLC eluted with hexane/acetone (9:1 to $7: 1)$ to afford compounds $1(0.7 \mathrm{mg})$ and $\mathbf{6}(1.1 \mathrm{mg})$. Fraction 15 , eluted with hexane/EtOAc (5:1), was further purified by silica gel column, using hexane/EtOAc (5:1) as eluent to afford compound 2 (10.4 mg). A combined mixture of fractions 17-19 was purified by normal phase HPLC by using hexane/EtOAc (4:1) and then hexane/acetone $(5: 1)$ as eluents to afford compound 5 (3.5 mg). Fraction 20, eluted with hexane/EtOAc (3:1), was further purified by normal phase HPLC using hexane/acetone (5:1 to $3: 1)$ to give compounds 7 (1.0 mg), 4 (0.8 mg), and 3 (1.1 mg).

Methyl-( $\left.1 S^{*}, 4 S^{*}, 5 S^{*}, 9 R^{*}, 11 S^{*}\right)-4,5$-epoxycaryophyllen-13oate (1): Colorless oil; $[\alpha]_{\mathrm{D}}^{25}+42.8\left(c 0.16, \mathrm{CHCl}_{3}\right)$; IR ( $\left.\mathrm{KBr}\right)$ $v_{\max } 1728,1653 \mathrm{~cm}^{-1} ;{ }^{1} \mathrm{HNMR}$ and ${ }^{13} \mathrm{C}$ NMR data, see Tables 1 and 2; ESI-MS $m / z 287\left([\mathrm{M}+\mathrm{Na}]^{+}\right)$; HR-ESI-MS $m / z 287.1622$ $[\mathrm{M}+\mathrm{Na}]^{+}$(calcd for $\mathrm{C}_{16} \mathrm{H}_{24} \mathrm{O}_{3} \mathrm{Na}, 287.1623$ ).

Gibberosin A (2): Colorless oil; $[\alpha]_{\mathrm{D}}^{25}+43.2\left(\right.$ c 1.04, $\left.\mathrm{CHCl}_{3}\right)$; IR (KBr) $v_{\max } 1716,1701,1653 \mathrm{~cm}^{-1} ;{ }^{1} \mathrm{HNMR}$ and ${ }^{13} \mathrm{CNMR}$ data, see Tables 1 and 2; ESI-MS $m / z 327\left([\mathrm{M}+\mathrm{Na}]^{+}\right)$; HR-ESIMS $m / z 327.1934[\mathrm{M}+\mathrm{Na}]^{+}$(calcd for $\mathrm{C}_{19} \mathrm{H}_{28} \mathrm{O}_{3} \mathrm{Na}, 327.1936$ ).

Gibberosin B (3): Colorless oil; $[\alpha]_{\mathrm{D}}^{25}+32.1\left(c 0.28, \mathrm{CHCl}_{3}\right)$; IR (KBr) $v_{\max }$ 3564, 1716, 1684, $1649 \mathrm{~cm}^{-1} ;{ }^{1} \mathrm{HNMR}$ and ${ }^{13} \mathrm{CNMR}$ data, see Tables 1 and 2; ESI-MS $m / z 357$ ([M + $\mathrm{Na}^{+}$); HR-ESI-MS $m / z 357.2041[\mathrm{M}+\mathrm{Na}]^{+}$(calcd for $\mathrm{C}_{20} \mathrm{H}_{30^{-}}$ $\mathrm{O}_{4} \mathrm{Na}, 357.2042$ )

Gibberosin C (4): Colorless oil; $[\alpha]_{\mathrm{D}}^{25}+13.3\left(\right.$ c $\left.0.32, \mathrm{CHCl}_{3}\right)$; IR (KBr) $v_{\max }$ 3568, 1716, 1684, $1653 \mathrm{~cm}^{-1} ;{ }^{1} \mathrm{HNMR}$ and ${ }^{13} \mathrm{CNMR}$ data, see Tables 1 and 2; ESI-MS $\mathrm{m} / \mathrm{z} 357$ ([M + $\mathrm{Na}]^{+}$); HR-ESI-MS $m / z 357.2041[\mathrm{M}+\mathrm{Na}]^{+}$(calcd for $\mathrm{C}_{20} \mathrm{H}_{30} 0^{-}$ $\left.\mathrm{O}_{4} \mathrm{Na}, 357.2042\right)$.

Gibberosin D (5): Colorless oil; $[\alpha]_{\mathrm{D}}^{25}+64.3\left(c 0.28, \mathrm{CHCl}_{3}\right)$; IR $(\mathrm{KBr}) v_{\max } 1734,1701,1653 \mathrm{~cm}^{-1} ;{ }^{1} \mathrm{H} \mathrm{NMR}$ and ${ }^{13} \mathrm{CNMR}$ data, see Tables 1 and 2; ESI-MS $m / z 385\left([\mathrm{M}+\mathrm{Na}]^{+}\right)$; HR-ESIMS $m / z$ 385.2352 [M + Na] ${ }^{+}$(calcd for $\mathrm{C}_{22} \mathrm{H}_{34} \mathrm{O}_{4} \mathrm{Na}, 385.2355$ ).

Gibberosin E (6): Colorless oil; $[\alpha]_{\mathrm{D}}^{25}+25.0\left(c 0.44, \mathrm{CHCl}_{3}\right)$; IR (KBr) $v_{\max } 1716,1670,1653 \mathrm{~cm}^{-1} ;{ }^{1} \mathrm{HNMR}$ and ${ }^{13} \mathrm{CNMR}$ data, see Tables 1 and 2; ESI-MS $m / z 325\left([\mathrm{M}+\mathrm{Na}]^{+}\right)$; HR-ESIMS $m / z$ 325.2146 [M + Na] ${ }^{+}$(calcd for $\mathrm{C}_{20} \mathrm{H}_{30} \mathrm{O}_{2} \mathrm{Na}, 325.2143$ ).

Gibberosin F (7): Colorless oil; $[\alpha]_{\mathrm{D}}^{25}+68.7\left(c 0.16, \mathrm{CHCl}_{3}\right)$; IR (KBr) $\nu_{\max } 1734,1716,1670,1653 \mathrm{~cm}^{-1} ;{ }^{1} \mathrm{HNMR}$ and ${ }^{13} \mathrm{CNMR}$ data, see Tables 1 and 2; ESI-MS $\mathrm{m} / \mathrm{z} 383$ ([M+ $\mathrm{Na}]^{+}$); HR-ESI-MS $m / z$ 383.2197 $[\mathrm{M}+\mathrm{Na}]^{+}$(calcd for $\mathrm{C}_{22} \mathrm{H}_{32}{ }^{-}$ $\mathrm{O}_{4} \mathrm{Na}, 383.2198$ ).

Cytotoxicity Testing. Compounds were assayed for cytotoxicity against Hep G2, A549, and MDA-MB-231 cancer cells using the MTT [3-(4,5-dimethylthiazol-2-yl)-2,5-diphenyltetrazolium bromide] method. ${ }^{15}$ Freshly trypsinized cell suspensions were seeded into a 96-well microtiter plate at densities of 500010000 cells per well and then the test compounds were added from DMSO-diluted stock solutions. After 3 days in culture, attached cells were incubated with MTT $\left(0.5 \mathrm{mg} \mathrm{mL}^{-1}, 1 \mathrm{~h}\right)$ and subsequently dissolved in DMSO. The absorbency at $550 \mathrm{~nm}$ was then measured using a microplate reader. $\mathrm{The}^{\mathrm{IC}} \mathrm{C}_{50}$ is the concentration of agent that reduced cell growth by $50 \%$ under the experimental conditions.

Financial support of this work provided by National Science Council of Taiwan (NSC94-2323-B-110-002) awarded to J.-H. Sheu was greatly appreciated.

\section{References}

1 J. W. Blunt, B. R. Copp, M. H. G. Munro, P. T. Northcote, M. R. Prinsep, Nat. Prod. Rep. 2005, 22, 15, and references therein.

2 J.-H. Sheu, A. F. Ahmed, R.-T. Shiue, C.-F. Dai, Y.-H. Kuo, J. Nat. Prod. 2002, 65, 1904, and references therein.

3 S.-L. Wu, P.-J. Sung, J.-H. Su, J.-H. Sheu, J. Nat. Prod. 2003, 66, 1252.

4 J.-H. Sheu, L.-F. Huang, S.-P. Chen, Y.-L. Yang, P.-J. Sung, G.-H. Wang, J.-H. Su, C.-H. Chao, W.-P. Hu, J.-J. Wang, J. Nat. Prod. 2003, 66, 917.

5 J.-H. Sheu, G.-H. Wang, C.-Y. Duh, K. Soong, J. Nat. Prod. 2003, 66, 662 .

6 A. F. Ahmed, J.-H. Su, R.-T. Shiue, X.-J. Pan, C.-F. Dai, Y.-H. Kuo, J.-H. Sheu, J. Nat. Prod. 2004, 67, 592.

7 A. F. Ahmed, J.-H. Su, Y.-H. Kuo, J.-H. Sheu, J. Nat. Prod. 2004, 67, 2079.

8 C.-H. Chao, L.-F. Huang, Y.-L. Yang, J.-H. Su, G.-H. Wang, M. Y. Chiang, Y.-C. Wu, C.-F. Dai, J.-H. Sheu, J. Nat. Prod. 2005, 68, 880 .

9 A. F. Ahmed, M.-H. Wu, G.-H. Wang, Y.-C. Wu, J.-H. Sheu, J. Nat. Prod. 2005, 68, 1051.

10 J.-H. Su, H.-C. Huang, C.-H. Chao, L.-Y. Yan, Y.-C. Wu, C.-C. Wu, J.-H. Sheu, Bull. Chem. Soc. Jpn. 2005, 78, 877.

11 Y.-J. Tseng, A. F. Ahmed, C.-F. Dai, M. Y. Chiang, J.-H. Sheu, Org. Lett. 2005, 7, 3813.

12 J. Jakupovic, E. Ellmauerer, F. Bohlmann, R. M. King, H. Robinson, Phytochemistry 1986, 25, 1927.

13 W.-R. Abraham, L. Ernst, B. Stumpf, Phytochemistry 1990, 29, 115.

14 a) J.-H. Sheu, S.-Y. Huang, C.-Y. Duh, J. Nat. Prod. 1996, 59, 23. b) J.-H. Sheu, S.-Y. Huang, G.-H. Wang, C.-Y. Duh, J. Nat. Prod. 1997, 60, 904.

15 M. C. Alley, D. A. Scudiero, A. Monks, M. L. Hursey, M. J. Czerwinski, D. L. Fine, B. J. Abbott, J. G. Mayo, R. H. Shoemaker, M. R. Boyd, Cancer Res. 1988, 48, 589. 